\title{
Vasyl Kapustyan (1942-2020) of blessed memory
}

\author{
Marina Gaidarzhy, Vitaliy Kolomiychuk, Vira Nikitina, Natalia Belemets
}

Acad. O.V. Fomin Botanical Garden, Taras Shevchenko National University of Kyiv, S. Petliury str. 1, 01032 Kyiv, Ukraine; botsad-fomin@ukr.net

\begin{abstract}
The article represents the scientific achievements and work of a Ukrainian botanist, candidate of agricultural sciences, director of the O.V. Fomin Botanical Garden (1987-2006, 2008-2012), Vasyl Kapustyan, who died on August 19, 2020, after a long illness.

Vasyl Kapustyan was born on July 24, 1942. In 1965 he graduated from the Ukrainian Agricultural Academy, and in 1972 received the degree of candidate of agricultural sciences. Since 1974, the work of Vasyl Kapustyan was associated with the O.V. Fomin Botanical Garden, where he served in 1975-1987 as deputy director and head of the sector of tropical and subtropical plants, in 1987-1997 - as director and head of the sector of tropical and subtropical plants, and from 1997 - exclusively as director of the Botanical Garden.

The scientific work of Vasyl Kapustyan was related to the introduction of tropical and subtropical plants, their conservation, and rational use. He was the author of over 80 scientific articles and monographs, the last of which was dedicated to the 180th anniversary of the botanical garden. Since the founding of the series "Introduction and Conservation of Plant Diversity" of the "Bulletin of the Taras Shevchenko National University of Kyiv", Vasyl Kapustyan was its editor-in-chief. He was also a member of the Academic Councils of Kyiv University and Faculty of Biology, chairman of the Academic Council of the Botanical Garden, a member of the Bureau of the Council of Botanical Gardens of Ukraine, and a member of the editorial board of the international scientific journal "Plant Introduction". He was the founder and scientific director of the Museum of the Botanical Garden History, which opened in 2004.
\end{abstract}

Keywords: Vasyl Kapustyan, director, botanical garden, plant introduction

On August 19, 2020, after a severe long illness, Vasyl Vasyliovych Kapustyan died at 79. He was a famous botanist-introducer, who for many years (1987-2006, 2008-2012) headed one of the oldest botanical gardens in Eastern Europe, the O.V. Fomin Botanical Garden.

Vasyl Kapustyan was born on July 24, 1942 in the village Khoruzhivka of Orzhytsia district, Poltava region. In 1965, he graduated from the Ukrainian Agricultural Academy. In 1972, he finished $\mathrm{PhD}$ courses at the Department of Plant Breeding of the same academy and defended the dissertation
"Productivity of annual forage crops and their mixtures in crop production in the southern part of Ukrainian Polissya". In 1972-1974, he worked at the Department of New Cultures of the M.M. Gryshko National Botanical Garden NAS of Ukraine. In 1974, he was appointed to the position of senior researcher at the O.V. Fomin Botanical Garden, and in 1975 - to the position of the deputy director. From 1975 until 1997, Vasyl Kapustyan also voluntarily served as the head of the Sector of Tropical and Subtropical Plants. In 2006, he became a senior researcher, and in 2016 he was 

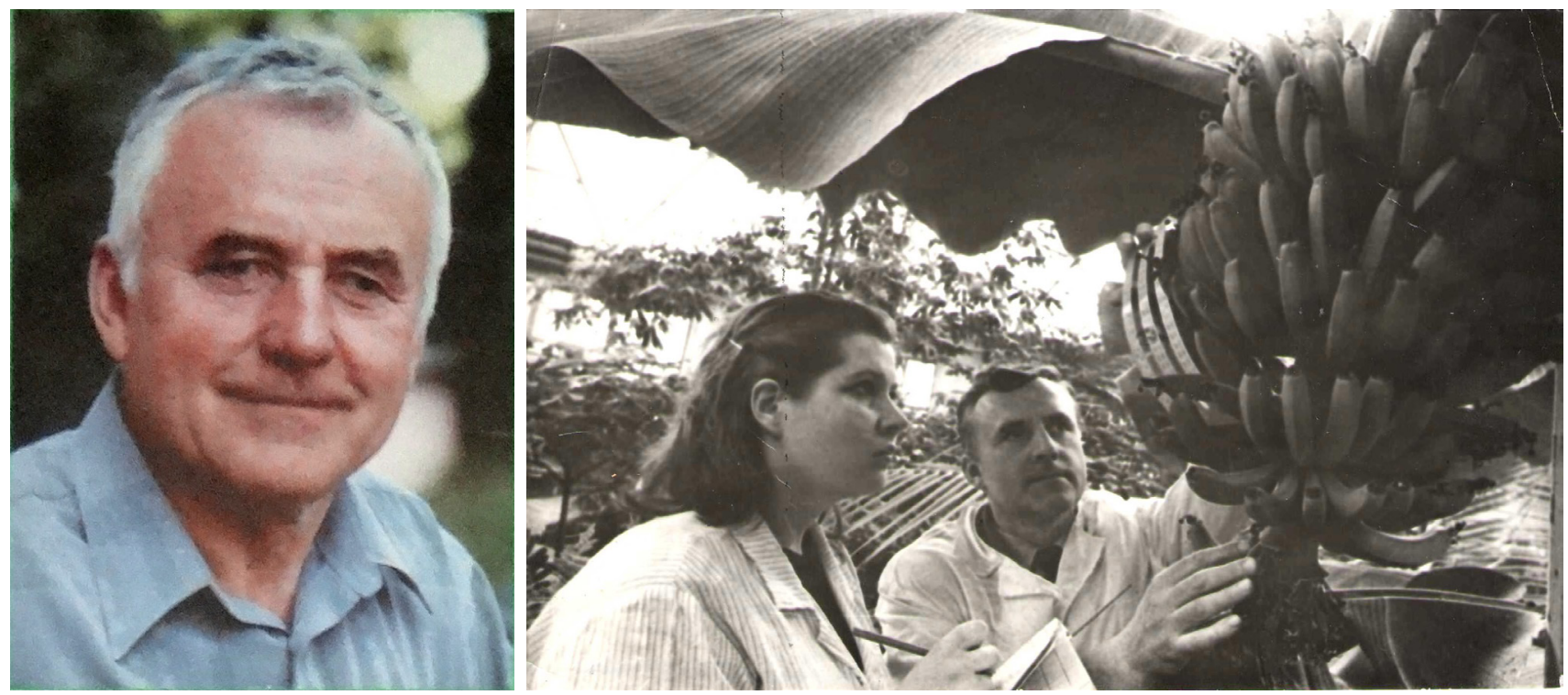

appointed the director of the Museum of the Botanical Garden History.

An extraordinary event happened in the early career of Vasyl Kapustyan as leader of the O.V. Fomin Botanical Garden. In 1985, it was decided that the exit from the metro station 'University' will locate on the territory of the botanical garden. Over 100 valuable tree species, a greenhouse complex covering about $600 \mathrm{~m}^{2}$, and the botanical garden's vital communications were to be destroyed. The administrations of the Kyiv University, biology faculty, and botanical garden strongly opposed this decision. They appealed to the State Committee for Nature Resources and the City Executive Committee and demanded to suspend these works. The people of Kyiv rose to defend the integrity of the botanical garden. Such respectable members of the Academy of Sciences of UkrSSR as K.M. Sytnyk and A.M. Grodzinskyi, as well as a corresponding member of the Academy of Sciences of UkrSSR Y.R. Shelyag-Sosonko, talked to the press regarding this situation. Faced with such strong opposition, the City Executive Committee decided to shift the subway exit aside from the botanical garden.

His scientific work was focused on the introduction of tropical and subtropical plants, their preservation and application. Hence, he applied the botanical-geographical principle during the formation of the expositions in subtropical and tropical greenhouses. The floristic area has been accepted as the basic unit for expositions in greenhouses, which allowed showing flora and, at the same time, partially vegetation of certain geographical regions of the world. For the first time, plants of relevant floristic areas and demonstrating certain morphological, systematic, and ecological features were planted in greenhouses at the O.V. Fomin Botanical Garden. In particular, five exhibits were created in the subtropical greenhouse and ten - in the tropical dome. The central places of these exhibits occupied plants having 100-150 and even more years: Livistona australis Vart., Araucaria bidwilii Hook., Howea forsteriana Becc., Jubaea chilensis (Molina) Baill., etc.

In different years, Vasyl Kapustyan was a research supervisor and research scientist of seven budget scientific themes performed at the O.V. Fomin Botanical Garden. During his directorship, employees of the botanical garden defended three doctoral and 17 candidate dissertations. In 1990, Vasyl Kapustyan with colleagues developed and patented the method of bananas growing in greenhouses. He paid considerable attention to the participation and hosting of the scientific conferences. In 1993, he was invited to take part in the XI Congress of the Botanical Gardens in China and visited the botanical gardens of Hangzhou, Shanghai, and Nanjing. Later, in 1994, he visited the Kew Botanical Gardens.

In 1999, the first issue of the series "Introduction and Conservation of Plant Diversity" of the "Bulletin of the Taras Shevchenko National University of Kyiv" was published. Vasyl Kapustyan became editor-inchief of the journal and held this position for 
many years. He was the founder and scientific director of the Museum of the Botanical Garden History, holding the collections dedicated to prominent academicians S.G. Navashin and O.V. Fomin.

Vasyl Kapustyan was the author and coauthor of over 80 scientific articles and monographs, among which is the latest one, dedicated to the 180-year history of the botanical garden. In cooperation with Y.Y. Sikura he published several monographs, six issues of the handbook "Morphology of fruits and seeds of flowering plants of the world flora", and jointly organized the International Conference "Fruit and Seed Science" in 2005.

For 23 years, Vasyl Kapustyan was a member of the Kyiv University Academic Councils, Faculty of Biology, and a chairman of the Academic Council of the O.V. Fomin Botanical Garden. He also was a member of the
Bureau of the Council of Botanical Gardens of Ukraine and a member of the editorial board of the international scientific journal "Plant Introduction". In 1999-2003, he was elected a deputy of the Starokyivka District in Kyiv. He was awarded the III class Order of Merit, the badge "Honored Worker of Education of Ukraine", the award of the Academic Council of the Kyiv University, and the Fomin's medal "For scientific achievements".

During his lifetime, Vasyl Kapustyan gained authority among his colleagues, who treated him with sincere kindness and respect. He loved the botanical garden and had the sincere consolation that citizens and guests of the city can admire this part of nature. The bright memory of Vasyl Vasyliovych Kapustyan will forever remain in the hearts of colleagues and friends.

\section{Світлій пам'яті Василя Васильовича Капустяна}

Марина Гайдаржи, Віталій Коломійчук, Віра Нікітіна, Наталія Белемець

Ботанічний сад ім. акад. О.В. Фоміна Київського національного університету імені Тараса Шевченка, вул. Симона Петлюри, 1, Київ, 01032, Україна; botsad-fomin@ukr.net

У статті висвітлено науковий доробок і трудову діяльність Василя Васильовича Капустяна - ботаніка, кандидата сільськогосподарських наук, директора Ботанічного саду ім. акад. О.В. Фоміна (19872006, 2008-2012), який помер 19 серпня 2020 року після тривалої хвороби.

Народився В.В. Капустян 24 липня 1942 р. 1965 року закінчив Українську сільськогосподарську академію, 1972 отримав ступінь кандидата сільськогосподарських наук. 31974 р. трудова діяльність В.В. Капустяна була пов'язана з Ботанічним садом ім. акад. О.В. Фоміна, де у 1975-1987 рр. він виконував обов'язки заступника директора з наукової роботи та керівника сектору тропічних і субтропічних рослин, у 1987-1997рр. - директора Ботанічного саду та завідувача сектору тропічних та субтропічних рослин, а з 1997 р. - виключно директора Ботанічного саду.

Наукова робота В.В. Капустяна була пов'язана з інтродукцією тропічних і субтропічних рослин, їхнім збереженням та раціональним використанням. В.В. Капустян був автором понад 80 наукових праць, монографічних робіт, остання з яких присвячена 180-річчю з дня заснування Ботанічного саду. В.В. Капустян був головним редактором Вісника Київського національного університету імені Тараса Шевченка "Інтродукція та збереження рослинного різноманіття" з часу його заснування. Також багато років він був членом Вченої Ради Київського університету та біологічного факультету, головою Вченої Ради Ботанічного саду, членом бюро Ради ботанічних садів України і членом редколегії міжнародного наукового журналу “Інтродукція рослин”. В.В. Капустян був організатором та науковим керівником Музею історії Ботанічного саду, відкритого 2004 року. 